\title{
No role for estrogen receptor I gene intron I Pvu II and exon 4 C325G polymorphisms in migraine susceptibility Natalie J Colson ${ }^{1}$, Rod A Lea ${ }^{1,2}$, Sharon Quinlan¹ and Lyn R Griffiths*1
}

Address: ${ }^{1}$ Genomics Research Centre, School of Health Science, Griffith University Gold Coast, PMB 50, Gold Coast Mail Centre, Queensland, 9726, Australia and ${ }^{2}$ Institute of Environmental Science and Research, 34 Kenepuru Drive, Porirua Wellington, New Zealand

Email: Natalie J Colson - n.colson@griffith.edu.au; Rod A Lea - Rod.Lea@esr.cri.nz; Sharon Quinlan - s.quinlan@griffith.edu.au; Lyn R Griffiths* - l.griffiths@griffith.edu.au

* Corresponding author

Published: 28 February 2006

BMC Medical Genetics2006, 7:12 doi:10.1 186/147I-2350-7-12
Received: 21 October 2005

Accepted: 28 February 2006

This article is available from: http://www.biomedcentral.com/I47/-2350/7//2

(C) 2006Colson et al; licensee BioMed Central Ltd.

This is an Open Access article distributed under the terms of the Creative Commons Attribution License (http://creativecommons.org/licenses/by/2.0), which permits unrestricted use, distribution, and reproduction in any medium, provided the original work is properly cited.

\begin{abstract}
Background: We have previously reported an association between the estrogen receptor I (ESRI) gene exon 8 G594A polymorphism and migraine susceptibility in two independent Australian cohorts. In this paper we report results of analysis of two further single nucleotide polymorphisms (SNPs) in the ESRI gene in the same study group, the T/C Pvu II SNP in intron I and the C325G SNP in exon 4, as well as results of linkage disequilibrium (LD) analysis on these markers.
\end{abstract}

Methods: We investigated these variants by case-control association analysis in a cohort of 240 migraineurs and 240 matched controls. The SNPs were genotyped using specific restriction enzyme assays. Results were analysed using contingency table methods incorporating the chi-squared statistic. LD results are presented as $D^{\prime}$ statistics with associated $P$ values.

Results: We found no evidence for association of the Pvu II T/C polymorphism and the C325G polymorphism and migraine susceptibility and no evidence for LD between these two SNPs and the previously implicated exon 8 G594A marker.

Conclusion: We have found no role for the polymorphisms in intron I and exon 4 with migraine susceptibility. To further investigate our previously implicated exon 8 marker, we suggest the need for studies with a high density of polymorphisms be undertaken, with particular focus on markers in LD with the exon 8 marker.

\section{Background}

Migraine is a frequent debilitating neurological disorder that affects a significant proportion of the population. The pathophysiology of migraine is not fully understood, although cortical hypersensitivity, vasospasm, neurotransmitters, especially serotonin (5-hydroxytryptamine, 5-HT), platelet activation and sympathetic hyperactivity all appear to play a part, whether as part of the primary triggering event, or as a response mechanism. In the absence of any biological marker, migraine diagnosis is currently based on subjective criteria alone. To further compound the problem, treatment efficacy is limited. Migraine imparts a significant burden on society, both socially and financially. The World Health Organization has identified migraine among the world's top 20 leading causes of disability, with an impact that extends far beyond individual suffering [1]. 


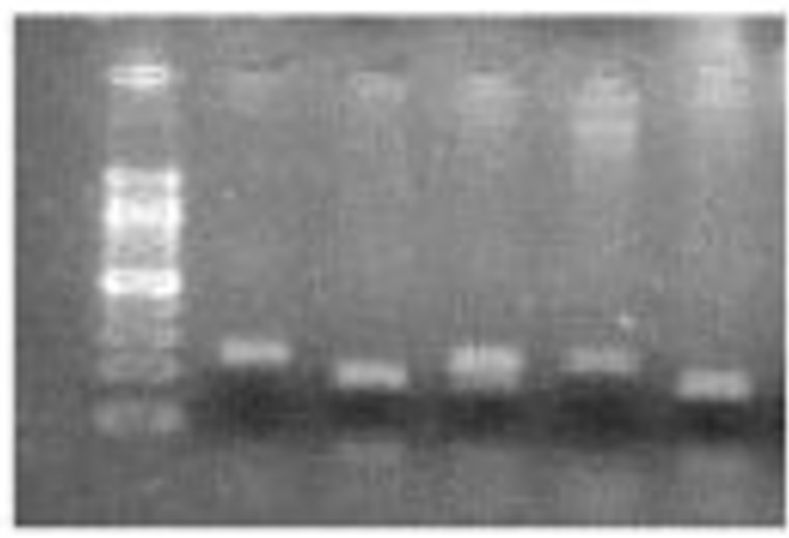

\section{Figure I}

Electrophoretogram of ESR I Pvu II genotypes. Lane I shows the 100 bp ladder. Lanes $2 \& 5$ show 239 bp fragments representing TT genotypes. Lanes $3 \& 6$ show 99 and faint 39 bp fragments representing CC genotypes. Lane 4 shows 239, 99 and faint $39 \mathrm{bp}$ fragments representing TC genotypes.

There is significant evidence from family and twin studies to indicate a strong genetic component to migraine. The current understanding of migraine is that it is a polygenic multifactorial disorder [2]. It has been postulated that genetic factors set the individual migraine threshold, with environmental influences playing a modulating role [3]. It is likely that many genes may provide an important although small contribution to an individual's migraine susceptibility [4]. The identification of migraine susceptibility genes has been the focus of substantial research to date and could eventually lead to improved treatments and greater understanding of the disorder. Several loci have shown promise, although these need to be followed up by both replication and functional studies to determine a definitive causative role [5-15].

The estrogen receptor 1 (ESR1) gene is a potential migraine candidate due to the well-known hormonal influence on migraine susceptibility. Migraines in women frequently occur during the childbearing years and are often influenced by significant hormonal milestones. The fluctuating hormone levels of the menstrual cycle have been implicated in migraine but a definitive role is yet to be established [16]. It has been suggested that factors additional to the circulating hormone levels may be at play [17]. Thus, we considered that variation in the ESR1 gene may confer increased migraine risk. To investigate the potential role of ESR1 in migraine we conducted an association study of the ESR1 G594A polymorphism (rs2228480) and migraine in two independent case-control groups. These previously reported results showed that individuals who carried the 594A allele were twice as likely to suffer from migraine than those who carried the 594G allele [18]. The G594A polymorphism is in exon 8 of ESR1, a gene of approximately 295 kilobases in size and consisting of 8 exons. It is a synonymous polymorphism with no associated amino acid change, consequently it is unlikely that this polymorphism is causative, but may be in linkage disequilibrium (LD) with an unknown causative variant. In this study we have analysed two further single nucleotide polymorphisms (SNPs) in ESR1 in the same study group, the Pvu II C/T SNP in intron 1 (rs2234693,) and the C325G SNP in exon 4 (rs1801132) which is located in the hormone binding region. The Pvu II locus has been associated with variation in estradiol levels in post menopausal women [19] and with an increased risk of stroke in men [20]. Interestingly both estrogen withdrawal and high estrogen concentrations have been implicated in migraine susceptibility in women [16], and there is evidence for an increased risk of stroke in MA sufferers [21]. It has been reported that the C325G SNP may play a role in calcium metabolism [22] and susceptibility to breast cancer $[23,24]$ a disease in which hormones play a role. The minor allele at each of these SNPs has been shown to have a frequency of $>20 \%$ as determined in Australian and other Caucasian populations $[25,26]$.

\section{Methods \\ Subjects}

Research was approved by the Griffith University Ethics Committee for experimentation on human subjects. Informed consent was obtained from all participants prior to commencement. All were of Caucasian origin, and were recruited from the east coast of Australia through the Genomics Research Centre's patient clinic whereby each participant was interviewed, and completed a detailed questionnaire on personal and family medical history, migraine symptoms, age of onset, frequency, severity, treatment and response, and migraine triggers as previously described $[27,28]$. Migraine was diagnosed by a clinical neurologist as either migraine with aura (MA), or migraine without aura $(\mathrm{MO})$ based strictly on the widely accepted criteria specified by the International Headache Society [29]. The study population was comprised of 240 migraineurs and 240 unrelated control individuals. To minimize potential bias from population stratification, the control group was matched for sex, age (+/- 5 years), and ethnicity.

\section{Genotyping}

Both markers were amplified using polymerase chain reaction (PCR). For the ESR1 Pvu II marker primers used were those previously described by Lai et al., 2002 resulting in a $239 \mathrm{bp}$ fragment following PCR [30]. The $20 \mu \mathrm{l}$ PCR reaction mix contained $40 \mathrm{ng}$ genomic DNA, $0.2 \mu \mathrm{M}$ of each primer, $1 \times$ PCR buffer, $2 \mathrm{mM} \mathrm{MgCl} 2,0.2 \mathrm{mM}$ dNTPs and $0.2 \mu \mathrm{l} \mathrm{Taq}$ polymerase $(5 \mathrm{U} / \mu \mathrm{l})$. Thermocycler 


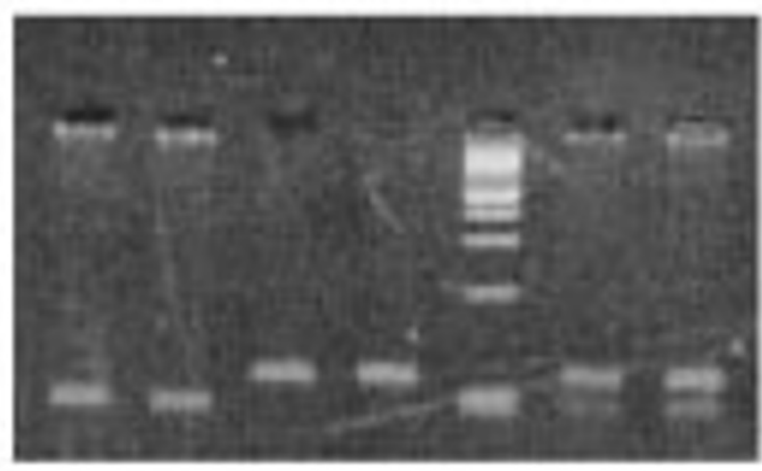

\section{Figure 2}

Electrophoretogram of ESR4 C325G genotypes. Lanes I \& 2 show 99 bp fragments representing GG genotypes (NB. the 21 bp fragment is not visible). Lanes 3 \& 4 show 120 bp fragments representing the $\mathrm{CC}$ genotypes. Lane 5 shows the 100 bp ladder. Lanes 6 \& 7 show the 120 bp \& 99 bp fragments representing $\mathrm{GC}$ heterozygotes.

conditions were $94^{\circ} \mathrm{C}$ for 2 minutes, 35 cycles of $94^{\circ} \mathrm{C}$ for 30 seconds, $55^{\circ} \mathrm{C}$ for 1 minute, with a final step of $72^{\circ} \mathrm{C}$ for 5 minutes. The $\mathrm{C}$ allele introduces a restriction site for the Pvu II enzyme, resulting in fragments of 140 and 99 base pairs. Following amplification, $10 \mu \mathrm{l}$ of product was digested with $\mathrm{Pvu}$ II overnight at $37^{\circ} \mathrm{C}$. After digestion, the product was loaded into a $2 \%$ high-resolution agarose gel stained with ethidium bromide and electrophoresed at 90 $\mathrm{V}$ for 30 minutes. An undigested sample indicated presence of the T allele. An electrophoretogram of the digested PCR product illustrating all genotypes appears in Figure 1.

The ESR1 C325G marker is a Hinfl restriction fragment length polymorphism (RFLP) [25]. Primers used were those previously described with minor modifications [31], (F 5'AGC CCG CTC ATG ATC AAA CG 3' R 5' GGA
TCA TAC TCG GAA TAG AGA AT 3') resulting in a 120 base pair fragment following PCR. The $20 \mu \mathrm{l}$ PCR reaction mix contained $50 \mathrm{ng}$ genomic DNA, $0.3 \mu \mathrm{M}$ of each primer, $1 \times$ PCR buffer, $2.25 \mathrm{mM} \mathrm{MgCl}_{2}, 0.2 \mathrm{mM}$ dNTPs and $0.2 \mu \mathrm{l} \mathrm{Taq}$ polymerase $(5 \mathrm{U} / \mu \mathrm{l})$. Thermocycler conditions were $94^{\circ} \mathrm{C}$ for 5 minutes, 30 cycles of $94^{\circ} \mathrm{C}$ for 30 seconds, $62^{\circ} \mathrm{C}$ for 1 minute and $72^{\circ} \mathrm{C}$, with a final step of $72{ }^{\circ} \mathrm{C}$ for 5 minutes. The $\mathrm{G}$ allele at codon 325 in the ESR 1 gene introduces a restriction site for the Hinfl enzyme, resulting in fragments of 99 and 21 base pairs. Following amplification, $10 \mu \mathrm{l}$ of product was digested with HinfI overnight at $37^{\circ} \mathrm{C}$. After digestion, the product was loaded into a 5\% ultra high-resolution agarose gel stained with ethidium bromide and electrophoresed at $90 \mathrm{~V}$ for 60 minutes. An undigested sample indicated presence of the 594C allele. An electrophoretogram of the digested PCR product illustrating all genotypes appears in Figure 2. To reduce the likelihood of genotyping error, random repeat samples and negative controls were included in both assays.

\section{Statistical analysis}

Genotype data and allele frequencies were compared between the migraine case and control groups using standard chi-square analysis. Due to multiple testing, the Bonferroni correction for 5 tests was applied, which set the level of significance at 0.01 (ie. 0.05/5).

Linkage disequilibrium between the ESR1 intron 1, the ESR1 exon 4 polymorphism and the previously reported exon 8 polymorphism that was tested in the same study group was analysed using the 2LD program [13]. LD results are presented as $\mathrm{D}^{\prime}$ and $\mathrm{P}$ values.

\section{Results and Discussion Case Control analysis}

Statistical analysis of the Pvu II marker revealed no significant difference between genotyped migraineurs and the matched control group with regard to genotype frequen-

Table I: Distribution of ESR Intron I Pvu II Polymorphism frequencies in migraineurs and controls

\begin{tabular}{|c|c|c|c|c|c|c|}
\hline & \multicolumn{3}{|c|}{ Genotypes } & \multirow[b]{2}{*}{$\mathbf{n}$ alleles } & \multicolumn{2}{|c|}{ Alleles } \\
\hline & CC & CT & TT & & C & $\mathbf{T}$ \\
\hline Migraine & 55 (24\%) & $122(53 \%)$ & 54 (23\%) & 462 & 232 (50\%) & $230(50 \%)$ \\
\hline MA & $29(20 \%)$ & 84 (58\%) & $32(22 \%)$ & 290 & 142 (49\%) & $148(5 \mid \%)$ \\
\hline MO & 22 (30\%) & 33 (45\%) & $18(25 \%)$ & 146 & 77 (53\%) & 69 (47\%) \\
\hline$M A \&$ MO & 4 & 5 & 4 & 26 & 13 (50\%) & 13 (50\%) \\
\hline Male & 17 (27\%) & 31 (48\%) & 16 (25\%) & 128 & $65(51 \%)$ & $63(49 \%)$ \\
\hline Female & $38(23 \%)$ & 91 (54\%) & 38 (23\%) & 334 & $167(50 \%)$ & $167(50 \%)$ \\
\hline Control & $46(23 \%)$ & 97 (48\%) & 59 (29\%) & 404 & $189(47 \%)$ & $215(53 \%)$ \\
\hline Male & 12 (19\%) & 27 (44\%) & $23(37 \%)$ & 124 & $5 \mid(4 \mid \%)$ & 73 (59\%) \\
\hline Female & 34 (24\%) & $70(50 \%)$ & $36(26 \%)$ & 280 & 138 (49\%) & $142(5 \mid \%)$ \\
\hline
\end{tabular}


cies $\left(\chi^{2}=1.94, \mathrm{P}=0.38\right)$ and allele frequencies $\left(\chi^{2}=1.02\right.$, $\mathrm{P}=0.31)$. Furthermore, no significant difference was seen when the migraine population was subdivided into MA (genotype frequencies $\chi^{2}=3.53, \mathrm{P}=0.17$, allele frequencies $\chi^{2}=0.320, \mathrm{P}=0.57$ ) and $\mathrm{MO}$ (genotype frequencies $\chi^{2}=1.66, \mathrm{P}=0.44$, allele frequencies $\chi^{2}=1.52, \mathrm{P}=0.22$ ), although the increased frequency of the CC genotype in MO (30\%) compared to MA (20\%) may warrant followup in a larger study group. There was no statistically significant difference in the migraine and control groups with regard to males (genotype frequencies $\chi^{2}=2.36, \mathrm{P}=0.31$, allele frequencies $\chi^{2}=2.36, \mathrm{P}=0.12$ ) and females (genotype frequencies $\chi^{2}=0.65, \mathrm{P}=0.72$, allele frequencies $\chi^{2}$ $=0.03, \mathrm{P}=0.86)$. With regard to male frequencies, it was interesting to note that there was a higher frequency of the CC genotype in male migraineurs (27\%) compared to the male control group (19\%). While this analysis did not reach statistical significance due to small numbers in the male subgroup, it may warrant further investigation in a larger study group, particularly in view of the previously reported role of the CC genotype in increased stroke risk in males [20] and the potential relationship between migraine and stroke [21,32-35]. Allele frequencies did not deviate from Hardy Weinberg Equilibrium in both case and control groups (at $\mathrm{P}=0.4, \mathrm{P}=0.6$ ) and were similar to previously reported frequencies [26]. Frequency distribution appears in Table 1.

Statistical analysis of the ESR1 C325G SNP also revealed no significant difference between genotyped migraineurs and the matched control group with regard to genotype frequencies $\left(\chi^{2}=4.19, P=0.12\right)$ and allele frequencies $\left(\chi^{2}\right.$ $=0.86, P=0.36)$. Furthermore, no significant difference was seen when the migraine population was subdivided into MA (genotype frequencies $\chi^{2}=5.26, P=0.07$, allele frequencies $\chi^{2}=1.67, P=0.20$ ) and MO (genotype frequencies $\chi^{2}=1.15 P=0.56$, allele frequencies $\chi^{2}=0.02, P$ $=0.90$ ), and males (genotype frequencies $\chi^{2}=2.54, P=$ 0.28 , allele frequencies $\chi^{2}=0.07, P=0.79$ ) and females (genotype frequencies $\chi^{2}=3.05, P=0.22$, allele frequencies $\left.\chi^{2}=1.53, P=0.22\right)$. Allele frequencies did not deviate from Hardy Weinberg Equilibrium in both case and control groups (at $P=0.1, P=0.3$ ) and were similar to frequencies previously reported in an Australian study group [25]. Frequency distribution appears in Table 2.

\section{Linkage Disequilibrium analysis}

There was no evidence for pairwise linkage disequilibrium between the exon 4 and exon 8 markers and the intron 1 and exon 8 markers. There was however, evidence for linkage disequilibrium between the intron 1 and exon 4 markers $\left(D^{\prime}=0.268, p=0.0001\right)$. Table 3 shows $D^{\prime}$ and $P$ values generated by the LD analysis as well as the physical distance between the markers. The distance calculations were performed using information on genomic location of the relevant SNP provided by Ensembl v.34, Oct 2005 [36].

\section{Conclusion}

The human ESR1 gene is located on chromosome 6q25.1 and contains 8 exons [31]. It is widely expressed in a broad range of tissues including $\mathrm{CNS}$ areas such as the hypothalamus, limbic system, hippocampus, cortices of the temporal lobe and the brainstem [37]. Numerous studies have demonstrated the multifunctional role of the ESR, particularly in the CNS. It is understood to play a role in neuroprotection via activation of the MAPK pathway [38], as well as in cognition, mood, and memory [39]. ESR can be activated by neurotransmitters and growth factors, in particular, dopamine [40]. Estrogens can induce $\mathrm{Ca}^{2+}$ mobilization, and activate several kinases including protein kinase $\mathrm{C}$, and phosphatidylinositol-3-OH kinase $[41,42]$. Estrogen deficiency has been implicated in pathological and degenerative processes in the CNS, while elevated levels have been involved in the development and progression of tumours [43]. In view of the wide variety of mechanisms under control of estrogen and its cognate receptor, particularly in known migraine pathways in the

Table 2: Distribution of ESR Exon 4 Codon C325G Polymorphism frequencies in migraineurs and controls

\begin{tabular}{|c|c|c|c|c|c|c|}
\hline & \multicolumn{3}{|c|}{ Genotypes } & \multirow[b]{2}{*}{$\mathrm{n}$ alleles } & \multicolumn{2}{|c|}{ Alleles } \\
\hline & CC & CG & GG & & C & G \\
\hline Migraine & 133 (58\%) & 90 (39\%) & $8(3 \%)$ & 462 & 356 (77\%) & 106 (23\%) \\
\hline MA & 77 (55\%) & 59 (42\%) & $5(3 \%)$ & 282 & $213(76 \%)$ & $69(24 \%)$ \\
\hline MO & 47 (62\%) & 26 (35\%) & $2(3 \%)$ & 150 & $120(80 \%)$ & $30(20 \%)$ \\
\hline$M A \& M O$ & 9 & 5 & I & 30 & $23(77 \%)$ & $7(23 \%)$ \\
\hline Male & 39 (6I\%) & $24(37 \%)$ & I (2\%) & 128 & $102(80 \%)$ & $26(20 \%)$ \\
\hline Female & $94(56 \%)$ & $66(40 \%)$ & $7(4 \%)$ & 334 & 254 (76\%) & 80 (24\%) \\
\hline Control & $160(64 \%)$ & 76 (3 I\%) & 13 (5\%) & 498 & 396 (79\%) & $102(21 \%)$ \\
\hline Male & $38(63 \%)$ & $18(30 \%)$ & $4(7 \%)$ & 120 & $94(78 \%)$ & $26(22 \%)$ \\
\hline Female & $122(64 \%)$ & $58(31 \%)$ & $9(5 \%)$ & 378 & $302(80 \%)$ & 76 (20\%) \\
\hline
\end{tabular}


Table 3: Linkage disequilibrium D' values (upper right hand side) and distance in bases between markers (lower left hand side).

\begin{tabular}{llll}
\hline Marker & Pvull & C325G & G594A \\
\hline Pvull & - & $D^{\prime}=0.268 P=0.0001$ & $D^{\prime}=0.016 P=0.52$ \\
C325G & 102188 bases & - & $D^{\prime}=0.060 P=0.71$ \\
G594A & $25676 I$ bases & I54573 bases & - \\
\hline
\end{tabular}

CNS, as well as the well-known role for hormones in migraine, variation in function of the estrogen receptor gene may play a role in neurological conditions, such as migraine. We have previously reported a role for the ESR1 G594A polymorphism in migraine susceptibility. This study investigated two further synonymous polymorphisms in ESR1, the widely studied Pvu II T/C polymorphism in intron 1 , and the $\mathrm{C} 325 \mathrm{G}$ polymorphism at exon 4.

Results showed no association with migraine in the casecontrol groups for both the intron 1 Pvu II marker and the exon 4 C325G marker. There was no evidence for LD between the exon 4 marker and the previously studied exon 8 marker nor between the intron 1 and exon 8 markers. The physical distance between the loci is $\sim 155 \mathrm{~kb}$ for exon 4 and 8 markers, and $\sim 257 \mathrm{~kb}$ between intron 1 and exon 8 markers. Absence of linkage disequilibrium at the same exon 4 and 8 loci has previously been reported in a different case-control panel by Curran et al (2001) [25]. Our study showed that there was evidence for linkage disequilibrium between the intron 1 and exon 4 markers which are $102 \mathrm{~kb}$ apart. Similar pairwise LD results between these two loci have been previously reported [44].

The fact that alleles of the two SNPs tested in the present study showed no association with migraine and were not in LD with alleles at the exon 8 SNP highlights the need for further studies with a high density of polymorphisms spanning the estrogen receptor to further investigate our previously reported susceptibility locus at exon 8 . In particular, such studies should focus on markers that are in LD blocks with the G594A polymorphism. Additionally, we believe further investigation of the exon 8 locus for a potential functional variant is clearly warranted, perhaps utilising allele specific gene expression methods. Also worthy of note is the recent report of an association of the exon $4 \mathrm{C} 325 \mathrm{G}$ polymorphism with migraine in women in a large Spanish cohort [44]. Although our results did not demonstrate this, there was an interesting trend in the female subgroup which we believe warrants further investigation in a larger study group.

\section{Competing interests}

The author(s) declare that they have no competing interests.

\section{Authors' contributions}

NC carried out the majority of the genotyping and data analysis and drafted the manuscript. The data analysis was supervised by RL, who also helped draft the manuscript. SQ oversaw recruitment, diagnosis, and clinical characterization of the subjects used in this study. LG conceived of the study, and participated in its design and coordination and helped to draft the manuscript. All authors read and approved the final manuscript.

\section{Acknowledgements}

This work was supported by funding from NHMRC and the Australian Brain Foundation. NC was supported by a Griffith University Postgraduate Scholarship and RL by an NHMRC CJ Martin Postdoctoral Fellowship.

\section{References}

I. WHO: The World Health Report. Mental Health: New Understanding, New Hope. [http://www.who.int/whr200I/].

2. Montagna P: Molecular genetics of migraine headaches: a review. Cephalalgia 2000, 20:3-14.

3. Ophoff RA, van den Maagdenberg AM, Roon KI, Ferrari MD, Frants RR: The impact of pharmacogenetics for migraine. Eur J Pharmacol 200I, 4I 3: I- I0.

4. Peroutka SJ: Sympathetic look at genetic basis of migraine. Headache 2002, 42:378-38I.

5. Kowa H, Fusayasu E, Ijiri T, Ishizaki K, Yasui K, Nakaso K, Kusumi M, Takeshima T, Nakashima K: Association of the insertion/deletion polymorphism of the angiotensin I-converting enzyme gene in patients of migraine with aura. Neurosci Lett 2005, 374:|29-|3|.

6. Colson NJ, Lea RA, Quinlan S, MacMillan J, Griffiths LR: Investigation of hormone receptor genes in migraine. Neurogenetics 2005, 6: 17-23.

7. Marziniak M, Mossner R, Schmitt A, Lesch KP, Sommer C: A functional serotonin transporter gene polymorphism is associated with migraine with aura. Neurology 2005, 64:157-I59.

8. Lea RA, Ovcaric M, Sundholm J, Solyom L, Macmillan J, Griffiths LR: Genetic variants of angiotensin converting enzyme and methylenetetrahydrofolate reductase may act in combination to increase migraine susceptibility. Brain Res Mol Brain Res 2005, 136: II2-117.

9. McCarthy LC, Hosford DA, Riley JH, Bird MI, White NJ, Hewett DR, Peroutka SJ, Griffiths LR, Boyd PR, Lea RA, Bhatti SM, Hosking LK, Hood CM, Jones KW, Handley AR, Rallan R, Lewis KF, Yeo AJ, Williams PM, Priest RC, Khan P, Donnelly C, Lumsden SM, O'Sullivan J, See CG, Smart DH, Shaw-Hawkins S, Patel J, Langrish TC, Feniuk W, Knowles RG, Thomas M, Libri V, Montgomery DS, Manasco PK, Xu CF, Dykes C, Humphrey PP, Roses AD, Purvis IJ: Single-nucleotide polymorphism alleles in the insulin receptor gene are associated with typical migraine. Genomics 200।, 78: I35-149.

10. Kowa H, Yasui K, Takeshima T, Urakami K, Sakai F, Nakashima K: The homozygous C677T mutation in the methylenetetrahydrofolate reductase gene is a genetic risk factor for migraine. Am J Med Genet 2000, 96:762-764.

II. Lea RA, Dohy A, Jordan K, Quinlan S, Brimage PJ, Griffiths LR: Evidence for allelic association of the dopamine beta-hydroxylase gene (DBH) with susceptibility to typical migraine. Neurogenetics 2000, 3:35-40.

12. Paterna S, Di Pasquale P, D'Angelo A, Seidita G, Tuttolomondo A, Cardinale A, Maniscalchi T, Follone G, Giubilato A, Tarantello M, 
Licata G: Angiotensin-converting enzyme gene deletion polymorphism determines an increase in frequency of migraine attacks in patients suffering from migraine without aura. Eur Neurol 2000, 43:133-136.

13. Del Zompo M, Cherchi A, Palmas MA, Ponti M, Bocchetta A, Gessa GL, Piccardi MP: Association between dopamine receptor genes and migraine without aura in a Sardinian sample. Neurology 1998, 5 I:781-786.

14. Ogilvie $A D$, Russell MB, Dhall $P$, Battersby $S$, Ulrich V, Smith $C A$ Goodwin GM, Harmar AJ, Olesen J: Altered allelic distributions of the serotonin transporter gene in migraine without aura and migraine with aura. Cephalalgia 1998, 18:23-26.

15. Peroutka SJ, Wilhoit $\mathrm{T}$, Jones $\mathrm{K}$ : Clinical susceptibility to migraine with aura is modified by dopamine D2 receptor (DRD2) Ncol alleles. Neurology 1997, 49:20I-206.

16. MacGregor EA: Oestrogen and attacks of migraine with and without aura. Lancet Neurol 2004, 3:354-36I.

17. Epstein MT, Hockaday JM, Hockaday TD: Migraine and reporoductive hormones throughout the menstrual cycle. Lancet 1975, I:543-548

18. Colson NJ, Lea RA, Quinlan S, MacMillan J, Griffiths LR: The estrogen receptor I G594A polymorphism is associated with migraine susceptibility in two independent case/contro groups. Neurogenetics 2004, 5:129-133.

19. Schuit SC, de Jong FH, Stolk L, Koek WN, van Meurs JB, Schoofs MW, Zillikens MC, Hofman A, van Leeuwen JP, Pols HA, Uitterlinden AG Estrogen receptor alpha gene polymorphisms are associated with estradiol levels in postmenopausal women. Eur J Endocrinol 2005, I 53:327-334.

20. Shearman AM, Cooper JA, Kotwinski PJ, Humphries SE, Mendelsohn ME, Housman DE, Miller G]: Estrogen receptor alpha gene variation and the risk of stroke. Stroke 2005, 36:228I-2282.

21. Diener HC, Kurth T: Is migraine a risk factor for stroke? Neurology 2005, 64: |496-| 497.

22. Hoshino S, Hosoi T, Miyao M, Shiraki M, Orimo H, Ouchi Y, Inoue S Identification of a novel polymorphism of estrogen receptoralpha gene that is associated with calcium excretion in urine. J Bone Miner Metab 2000, 18:153-157.

23. Vasconcelos A, Medeiros R, Veiga I, Pereira D, Carrilho S, Palmeira C, Azevedo C, Lopes CS: Analysis of estrogen receptor polymorphism in codon 325 by PCR-SSCP in breast cancer: association with lymph node metastasis. Breast J 2002, 8:226-229.

24. Hsiao WC, Young KC, Lin SL, Lin PW: Estrogen receptor-alpha polymorphism in a Taiwanese clinical breast cancer population: a case-control study. Breast Cancer Res 2004, 6:RI80-6.

25. Curran JE, Lea RA, Rutherford S, Weinstein SR, Griffiths LR: Association of estrogen receptor and glucocorticoid receptor gene polymorphisms with sporadic breast cancer. Int J Cancer 200I, 95:27I-275.

26. Sasaki M, Tanaka $Y$, Sakuragi N, Dahiya R: Six polymorphisms on estrogen receptor I gene in Japanese, American and German populations. Eur J Clin Pharmacol 2003, 59:389-393.

27. Johnson MP, Lea RA, Curtain RP, MacMillan JC, Griffiths LR: An investigation of the 5-HT2C receptor gene as a migraine candidate gene. Am J Med Genet 2003, I I 7B:86-89.

28. Lea RA, Curtain RP, Hutchins C, Brimage PJ, Griffiths LR: Investigation of the CACNAIA gene as a candidate for typical migraine susceptibility. Am J Med Genet 200I, 105:707-7I2.

29. HCClHS: Headache Classification Committee for the International Headache Society. Classification and diagnostic criteria for headache disorders, cranial neuralgias and facial pain Ist edition. Cephalgia 1988, 8 (Suppl 7): I-96.

30. Lai IC, Liao DL, Bai YM, Lin CC, Yu SC, Chen JY, Wang YC: Association study of the estrogen receptor polymorphisms with tardive dyskinesia in schizophrenia. Neuropsychobiology 2002, 46:173-175.

31. Iwase H, Greenman JM, Barnes DM, Hodgson S, Bobrow L, Mathew CG: Sequence variants of the estrogen receptor (ER) gene found in breast cancer patients with ER negative and progesterone receptor positive tumors. Cancer Lett 1996 , 108: 179-184.

32. Etminan M, Takkouche B, Isorna FC, Samii A: Risk of ischaemic stroke in people with migraine: systematic review and metaanalysis of observational studies. Bmj 2005, 330:63.
33. Schwaag S, Nabavi DG, Frese A, Husstedt IW, Evers S: The association between migraine and juvenile stroke: a case-control study. Headache 2003, 43:90-95.

34. Merikangas KR, Fenton BT, Cheng SH, Stolar MJ, Risch N: Association between migraine and stroke in a large-scale epidemiological study of the United States. Arch Neurol 1997, 54:362-368.

35. Donaghy $M$, Chang CL, Poulter N: Duration, frequency, recency, and type of migraine and the risk of ischaemic stroke in women of childbearing age. J Neurol Neurosurg Psychiatry 2002, 73:747-750

36. Hubbard T, Andrews D, Caccamo M, Cameron G, Chen Y, Clamp M, Clarke L, Coates G, Cox T, Cunningham F, Curwen V, Cutts T, Down T, Durbin R, Fernandez-Suarez XM, Gilbert J, Hammond M, Herrero J, Hotz H, Howe K, lyer V, Jekosch K, Kahari A, Kasprzyk A, Keefe D, Keenan S, Kokocinsci F, London D, Longden I, McVicker G, Melsopp C, Meidl P, Potter S, Proctor G, Rae M, Rios D, Schuster M, Searle S, Severin J, Slater G, Smedley D, Smith J, Spooner W, Stabenau A, Stalker J, Storey R, Trevanion S, Ureta-Vidal A, Vogel J, White S, Woodwark C, Birney E: Ensembl 2005. Nucleic Acids Res 2005, 33:D447-53.

37. Osterlund MK, Grandien K, Keller E, Hurd YL: The human brain has distinct regional expression patterns of estrogen receptor alpha mRNA isoforms derived from alternative promoters. J Neurochem 2000, 75:1390-1397.

38. Mize AL, Shapiro RA, Dorsa DM: Estrogen receptor-mediated neuroprotection from oxidative stress requires activation of the mitogen-activated protein kinase pathway. Endocrinology 2003, |44:306-3|2

39. McEwen B: Estrogen actions throughout the brain. Recent Prog Horm Res 2002, 57:357-384.

40. Power RF, Mani SK, Codina J, Conneely OM, O'Malley BW: Dopaminergic and ligand-independent activation of steroid hormone receptors. Science 1991, 254:1636-1639.

4I. Kelly MJ, Levin ER: Rapid actions of plasma membrane estrogen receptors. Trends Endocrinol Metab 200I, I 2:152-I56.

42. Simoncini T, Hafezi-Moghadam A, Brazil D, Ley K, Chin W, Liao J: Interaction of estrogen receptor with regulatory subunit of phosphatidylinositol-OH kinase. Nature 2000, 407:

43. Diel P: Tissue-specific estrogenic response and molecular mechanisms. Toxicol Lett 2002, 127:217-224.

44. Wedren S, Lovmar L, Humphreys K, Magnusson C, Melhus H, Syvanen AC, Kindmark A, Landegren U, Fermer ML, Stiger F, Persson I, Baron J, Weiderpass E: Oestrogen receptor alpha gene haplotype and postmenopausal breast cancer risk: a case control study. Breast Cancer Res 2004, 6:R437-49.

\section{Pre-publication history}

The pre-publication history for this paper can be accessed here:

http://www.biomedcentral.com/1471-2350/7/12/prepub

Publish with Bio Med Central and every scientist can read your work free of charge

"BioMed Central will be the most significant development for disseminating the results of biomedical research in our lifetime. "

Sir Paul Nurse, Cancer Research UK

Your research papers will be:

- available free of charge to the entire biomedical community

- peer reviewed and published immediately upon acceptance

- cited in PubMed and archived on PubMed Central

- yours - you keep the copyright

Submit your manuscript here:

http://www.biomedcentral.com/info/publishing_adv.asp
BiolMedcentral 